\title{
Acknowledgment to Reviewers 2017
}

\author{
Dijana Vuletić ${ }^{1}$, Ivan Balenović ${ }^{2 *}$
}

(1) Editor-in-Chief of South-east European forestry Journal, Croatian Forest Research Institute, Common Affairs Service, Cvjetno naselje 41, HR-10450 Jastrebarsko, Croatia; (2) Executive Editor of South-east European forestry Journal, Croatian Forest Research Institute, Division for Forest Management and Forestry Economics, Trnjanska cesta 35, HR-10000 Zagreb, Croatia

Citation: VULETIĆ D, BALENOVIĆ | 2018 Acknowledg-ment to Reviewers 2017. South-east Eur for 9 (1): 89-90. DOI: https://dx.doi.org/10.15177/seefor.18-03

Published online: 30 Apr 2018

The editors of South-east European forestry would like to express their sincere gratitude to the following reviewers for evaluating manuscripts in 2017. Their generous contributions of time and expertise are greatly appreciated. Reviewers who evaluated two or more manuscripts in 2017 are underlined.

Arampatzis, Garyfallos; Democritus University of Thrace, Department of Forestry and Management of the Environment and Natural Resources (Orestiada, Greece)

Ayan, Sezgin; Kastamonu University, Faculty of Forestry (Kastamonu, Turkey)

Bajrić, Muhamed; University of Sarajevo, Faculty of Forestry (Sarajevo, Bosnia and Herzegovina)

Balenović, Ivan; Croatian Forest Research Institute (Jastrebarsko, Croatia)

Đodan, Martina; Croatian Forest Research Institute (Jastrebarsko, Croatia)

Gašparović, Mateo; University of Zagreb, Faculty of Geodesy (Zagreb, Croatia)

Goršić, Ernest; University of Zagreb, Faculty of Forestry (Zagreb, Croatia)

Hämäläinen, Esa; University of Turku, Brahea Centre (Turku, Finland)

Hernea, Cornelia; Banat's University of Agricultural Sciences and Veterinaty Medicine of Timisoara (Timisoara, Romania)

Indir, Krunoslav; Croatian Forest Research Institute (Jastrebarsko, Croatia)

Jurc, Dušan; Slovenian Forestry Institute (Ljubljana, Slovenia)

Koch, Steven Friedrich; University of Pretoria, Faculty of Economic and Management Sciences (Pretoria, Republic of South Africa)

Kos, Katarina; University of Ljubljana, Department of Agronomy (Ljubljana, Slovenia)
Kovačević, Branislav; Institute of Lowland Forestry and Environment (Novi Sad, Serbia)

Landekić, Matija; University of Zagreb, Faculty of Forestry (Zagreb, Croatia)

Magazin, Nenad; University of Novi Sad, Faculty of Agriculture (Novi Sad, Serbia)

Marčeta, Dane; University of Banja Luka, Faculty of Forestry (Banja Luka, Bosnia and Herzegovina)

Matošević, Dinka; Croatian Forest Research Institute (Jastrebarsko, Croatia)

Medved, Ivan; University of Zagreb, Faculty of Mining, Geology and Petroleum Engineering (Zagreb, Croatia)

Melika, George; Plant Health and Molecular Biology Laboratory, National Food Chain Safety Office, Directorate of Plant Protection, Soil Conservation and Agri-environment (Budapest, Hungary)

Merganičova, Katarina; Technical University in Zvolen, Faculty of Forestry (Zvolen, Slovakia)

Özel, Halil Barış; Bartin University, Faculty of Forest Engineering (Bartin, Turkey)

Paladinić, Elvis; Croatian Forest Research Institute (Jastrebarsko, Croatia)

Pilaš, Ivan; Croatian Forest Research Institute (Jastrebarsko, Croatia)

Pirc Barčić, Andreja; University of Zagreb, Faculty of Forestry (Zagreb, Croatia)

Rubinić, Vedran; University of Zagreb, Faculty of Agriculture (Zagreb, Croatia) 
Seletković, Ante; University of Zagreb, Faculty of Forestry (Zagreb, Croatia)

Simic Milas, Anita; Bowling Green State University, College of Arts and Sciences, School of Earth, Environment and Society (Bowling Green, $\mathrm{OH}$, USA)

Smreček, Róbert; Technical University in Zvolen, Faculty of Forestry (Zvolen, Slovakia)

Stojanović, Dejan; Institute of Lowland Forestry and Environment (Novi Sad, Serbia)

Šimunić, Ivan; University of Zagreb, Faculty of Agriculture (Zagreb, Croatia)

Šporčić, Mario; University of Zagreb, Faculty of Forestry (Zagreb, Croatia)

Štěpánek, Petr; Global Change Research Institute CzechGlobe, Department of Climate Modelling (Brno, Czech Republic)
Tikvić, Ivica; University of Zagreb, Faculty of Forestry (Zagreb, Croatia)

Trajkov, Pande; Ss. Cyril and Methodius University in Skopje, Faculty of Forestry in Skopje (Skopje, Macedonia)

Vilhar, Urša; Slovenian Forestry Institute (Ljubljana, Slovenia)

Vodacek, Anthony; Chester F. Carlson Center for Imaging Science, Rochester Institute of Technology (Rochester, NY, USA)

Vuletić, Dijana; Croatian Forest Research Institute (Jastrebarsko, Croatia)

Weiss, Gerhard; University of Natural Resources and Life Sciences, Institute of Forest, Environmental and Natural Resource Policy (Vienna, Austria)

Zgorelec, Željka; University of Zagreb, Faculty of Agriculture (Zagreb, Croatia) 